ORIGINAL ARTICLE

\title{
Açaí seed bran in the feed of slow-growth broilers
}

Janaína de Cássia Braga ARRUDA ${ }^{1 *}$, Lívia Anália Bentes da FONSECAํㅜ, Leonardo César Portal PINTO ${ }^{1}$ Higor César de Oliveira PINHEIRO ${ }^{1}$, Brenda Thamara Oliveira MONTEIRO ${ }^{1}$, Maria Cristina MANNO ${ }^{1}$, Kedson Raul de Souza LIMA¹, Ana Rita de LIMA²

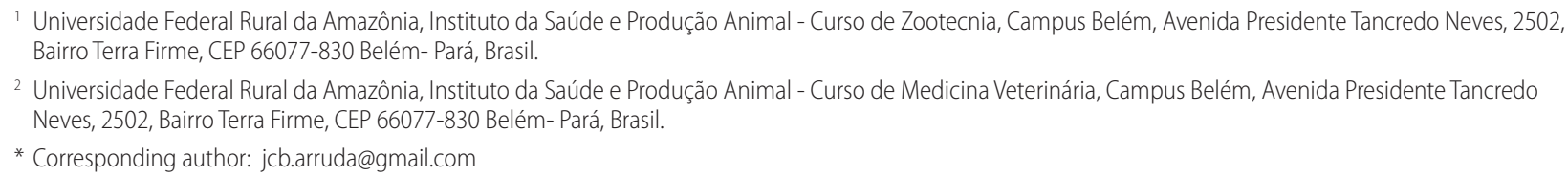

\begin{abstract}
The aim of this study was to analyze the potential use of açaí seeds as an alternative ingredient in the feed of slow-growth broilers until 28 days of age. We carried out a bromatological analysis of fractions of the açaí fruit. The açaí seed without mesocarp was the best choice for formulation of the açaí seed bran (ASB), which was evaluated in terms of bird performance and economic viability of the supplemented feed. A total of 416 male chicks of the French Red-Naked Neck lineage were used in a completely randomized design with four treatments $(0,2,6$ and $10 \%$ inclusion of ASBin the feed) with eight replicates each. The results indicated that ASB can be included in proportions of up to $10 \%$ in the diet of slow growth broilers at early development stage without impairing performance. The $10 \%$ inclusion level also was economically equal to the control treatment, representing a viable alternative for broiler production, with potential for reduction of the negative impacts generated by açaí residue in the environment.
\end{abstract}

KEYWORDS: alternative feed, chicken, agroindustrial residue, sustainability, Euterpe oleraceae

\section{Farelo de caroço de açaí em ração para frangos de crescimento lento}

\section{RESUMO}

Objetivou-se analisar o potencial da utilização do caroço de açaí como ingrediente alternativo na alimentação de frangos de corte de crescimento lento, até 28 dias de idade. Primeiramente foi feita a análise bromatológica de fraçóes do fruto do açaí, que resultou no caroço de açaí sem mesocarpo como sendo a melhor opção para a formulação do farelo de caroço de açaí (FCA). O farelo foi usado na composição de raçôes em um experimento de desempenho das aves. Ao final foi realizada uma análise da viabilidade econômica do uso de FCA em ração pata frangos. Utilizamos 416 pintos machos, da linhagem Francês Pescoço Pelado Vermelho, em um delineamento inteiramente casualisado com quatro tratamentos (0, 2, 6 e $10 \%$ de inclusão de FCA) de oito repetiçóes cada. Concluímos que o FCA pode ser incluído em até $10 \%$ na dieta para frango de corte de crescimento lento em fase inicial, sem ocasionar prejuízo em seu desempenho. O nível de $10 \%$ de inclusão mostrou-se economicamente equivalente ao tratamento controle, sendo uma alternativa viável de insumo na produção de frangos, que pode contribuir para a redução do impacto negativo gerado pelo resíduo do açaí no meio ambiente.

PALAVRAS-CHAVE: alimento alternativo, nutrição de frangos, resíduo agroindustrial, sustentabilidade, Euterpe oleraceae

\section{INTRODUCTION}

Poultry production has been the fastest growing agricultural sector in recent years, and, due to improvements in production processes (Moreira et al. 2012), it has been adapting to meet the demand of a new consumer market concerned with ecologically sustainable production coupled with food security and differential meat flavor (Braga and Roque 2008; Guéguen and Pascal 2010). This has resulted in the production of slow growth broilers, commonly known in Brazil as frango caipira (free range chicken) or frango colonial (colonial chicken), which have lower potential for growth, zootechnical performance, and yield of the noble parts when compared to fast-growing industrial chickens, or "white chickens". However, the better taste, firmer texture and more pronounced color of slowgrowth broiler meat make it a promising niche-market product (Nahashon et al. 2010; Morais et al. 2015). The late slaughter age of slow-growth broilers results in higher production costs, which makes it desirable to seek alternative ingredients for feed that reduce costs without compromising poultry performance 
(Camelo et al. 2015; Tavares et al. 2015). Several studies have tested the efficacy of agroindustrial byproducts for this purpose (Sousa et al. 2012; Delgado et al. 2013). Another goal is to successfully replace soybean meal and maize in chicken feed, because the price of these products oscillates strongly, and their supply varies seasonaly in many regions (Arruda et al. 2008; Camelo et al. 2015).

Açaí (Euterpe oleracea Mart.) is the main fruit culture of economic value in the state of Pará, in the eastern Amazon region (Santana et al. 2014). The edible portion of the palmtree fruit is the pulp, which constitutes about $32 \%$ of the total fruit mass in relation to the $68 \%$ occupied by the seed (Yuyama et al. 2011). Brazil produced 216,071 tons of açaí in 2015, and the northern region of the country alone was responsible for 201,207 tons of the total production, representing 93\% of extracted açaí. The state of Pará produces $62 \%$ of the açaí from the northern region (IBGE 2015), and $90 \%$ of this volume corresponds to residues generated after the agroindustrial processing of the fruit for pulp production. These residues are basically composed of the seed and attached fibers, which have potential as renewable lignocellulosic material (Teixeira et al. 2002). The residue represents a serious environmental problem. In the city of Belém alone, approximately 255,000 tons of residual organic açaí waste are produced each year from fruit processing, which is equivalent to about 700 tons per day (Oliveira et al. 2007). Several methods have been investigated for the use of açaí agroindustrial residue, including energy generation and fertilizer production (Teixeira et al. 2002). The use of açaí seed has aroused the interest of animal producers, and, in some cases, it has been empirically tested in animal feed (Gomes et al. 2012).

We determined the bromatological characteristics of two different parts of the açaí fruit, and then used the component that showed the best bromatological performance to prepare a bran for use in three different concentrations in test feeds for slow-growth broilers in the initial growth phase from 1 to 28 days. We evaluated broiler performance and the economic viability of the proposed diets in order to assess the potential use of açaí residue as an alternative ingredient in broiler feed

\section{MATERIAL AND METHODS}

\section{Bromatological analyses}

Post-processing residues of açaí fruit pulp were obtained from the local trade of açaí juice producers at three commercial establishments in the city of Belém (Pará state). The residue was collected preferably immediately after removal of the pulp, then transferred to $50 \mathrm{~kg}$ raffia bags, transported to the preparation room, and washed for removal of the residual pulp sludge and any other attached material. The resulting product was then stored as açaí seed with mesocarp (AcM). Part of the material had the fibers (monostels) adhered to the mesocarp removed. After washing, the material was placed in $50-\mathrm{L}$ buckets and covered with water for 20 days to separate the mesocarp fibers through spontaneous anaerobic fermentation of the vegetable matter, aiding the release of fibrous bundles. The material was then re-washed and underwent a manual scarification process to complete the defibration technique according to Castilhos (2012). The end result was analyzed as açaí seed without mesocarp (AsM). The two end products (AcM or AsM) were transformed into açaí seed bran for use in broiler feed.

Samples of $500 \mathrm{~g}$ of AcM and AsM were weighed and placed in a forced ventilation oven at $55^{\circ} \mathrm{C}$ for $72 \mathrm{~h}$ to obtain $\mathrm{ADS}$ (air-dried samples). The ADS were then milled in a $16-\mathrm{mm}$ "knife-like" mill with 16 mash and $1 \mathrm{~mm}$ sieves, and stored separately in identified containers. Five composite samples of $300 \mathrm{~g}$ of AcM and five of AsM were formed using $100 \mathrm{~g}$ ADS from each establishment of origin, and were analyzed in triplicate for dry matter (DM), neutral detergent fiber (NDF) and acid detergent fiber (ADF) using the Kjeldahl method, and ether extract (EE) using the ANKOM method. The gross energy (GE) was determined using a calorimetric pump and crude fiber (CF) following the procedures described by Detmann et al. (2012). The amount of energy used by the broilers was estimated through the raw energy components, and their value was obtained through bomb calorimetry. The analyses were performed at the Animal Nutrition Laboratory (LABNUTAN) of the Health and Animal Production Institute (ISPA) of the Universidade Federal Rural da Amazônia, Belém campus.

\section{Broiler performance}

The experiment was carried out at the Experimental Performance Shed of the Poultry Sector of ISPA/UFRA Belém campus. We used 416 one-day-old male chicks (38.25 $\mathrm{g} \pm 0.40 \mathrm{~g}$ ) of the French Red-Naked Neck lineage obtained from the hatchery and already vaccinated against Marek's disease, Gumboro, Newcastle and bronchitis. The chicks were distributed among four treatments: T0: control diet without the açaí seed bran; T1: diet with inclusion of $2 \%$ açaí seed bran; T2: diet with inclusion of $6 \%$ açaí seed bran; T3: diet with inclusion of $10 \%$ açaí seed bran (Table 1). A completely randomized design was used, with eight replicates per treatments, and 13 birds per replicate, distributed in a total of 32 experimental boxes measuring $2.5 \mathrm{~m}^{2}$ each and a final density of 5.2 birds $\mathrm{m}^{-2}$ (13 birds per box). The experiment was finished when the birds reached 28 days of age.

Environmental conditions were standardized according to the breeding stage following methods adapted from Cassuce et al. (2013). We adopted a program of continuous light (12 hours natural +12 hours artificial light) with the initial heating provided by incandescent lamps $(250 \mathrm{w})$, using one unit per box. During the reception of the birds, they were individually weighed and distributed in such a way that the initial weight of the boxes was approximately the same. The birds received ad libitum water and food. The isoprotein, isovitamin and 
Table 1. Centesimal composition (\%) of rations fed to slow-growth broilers in the initial growth phase (1 to 28 days) submitted to different treatments of inclusion of açaí seed bran in their diet. T0: control diet without açaí seed bran;T1: diet with 2\% açaí seed bran;T2: diet with 6\% açaí seed bran; T3: diet with 10\% açaí seed bran.

\begin{tabular}{lcccc}
\hline \multirow{2}{*}{ Ingredients (\%) } & \multicolumn{4}{c}{ Treatments } \\
\cline { 2 - 5 } & T0 & T1 & T2 & T3 \\
\hline Corn (7.88\% CP*) & 61.12 & 57.87 & 51.36 & 44.84 \\
Soybean meal (45\% CP*) & 33.50 & 33.91 & 34.70 & 35.51 \\
Bicalcium phosphate (23\% & 1.42 & 1.42 & 1.43 & 1.44 \\
Ca/18\% P*) & 1.00 & 0.99 & 0.99 & 0.98 \\
Limestone (38\% Ca*) & 1.78 & 2.63 & 4.34 & 6.05 \\
Soybean oil (EM 8.790 kcal/kg*) & 0.48 & 0.48 & 0.48 & 0.48 \\
Salt & 0.10 & 0.10 & 0.10 & 0.10 \\
BHT & - & 2.00 & 6.00 & 10.00 \\
Açaí seed bran & 0.60 & 0.60 & 0.60 & 0.60 \\
\hline Premix & 100.00 & 100.00 & 100.00 & 100.00 \\
\hline TOTAL & & & & \\
\hline
\end{tabular}

Nutrients

\begin{tabular}{lllll}
\hline Metabolizable energy (Mcal/kg) & 2.980 .00 & 2.980 .00 & 2.980 .00 & 2.980 .00
\end{tabular}

$\begin{array}{lllll}\text { Crude protein (\%) } & 20.00 & 20.00 & 20.00 & 20.00\end{array}$

$\begin{array}{lllll}\text { Calcium (\%) } & 0.86 & 0.86 & 0.86 & 0.86\end{array}$

$\begin{array}{lllll}\text { Available P (\%) } & 0.38 & 0.38 & 0.38 & 0.38\end{array}$

$\begin{array}{lllll}\text { Sodium (\%) } & 0.21 & 0.21 & 0.21 & 0.21\end{array}$

$\begin{array}{lllll}\text { Ether extract (\%) } & 4.56 & 5.29 & 6.76 & 8.22\end{array}$

${ }^{*} \mathrm{CP}=$ crude protein; $\mathrm{Ca}=$ Calcium; $\mathrm{P}=$ Phosphorus; $\mathrm{ME}=$ metabolizable energy . 'Guarantee levels per kilogram of product: Vitamin A 1.333.333.00 IU; Vitamin B1 166.00 mg; Vitamin B12 1.666.00 $\mu$ g; Vitamin B2 $666.00 \mathrm{mg}$; Vitamin B6 166.00 mg; Vitamin D3 300.000.00 Ul; Vitamin E 2.000.00 Ul; Vitamin K3 333.00 mg; Biotin $6.00 \mathrm{mg}$; Cholin 36.0 g; Niacin $4.666 .00 \mathrm{mg}$; Folic acid $67.00 \mathrm{mg}$; Pantothenic acid $1.717 .00 \mathrm{mg}$; Cobalt $16.00 \mathrm{mg}$ : Copper $1.000 .00 \mathrm{mg}$; Iron $8.333 .00 \mathrm{mg}$; lodine $166.00 \mathrm{mg}$; Manganese $10.83 \mathrm{~g}$; Selenium $33.00 \mathrm{mg}$; Zinc 7.500.00 mg; Methionine 233.33 g; Bacillus subtilis 50.000.000.000.00 UFC; Halquinol $5.000 .00 \mathrm{mg}$; Salinomicin $10.99 .00 \mathrm{~g}$.

isomineral diets were formulated to meet the nutritional requirements of the initial phase, and these methods were adapted from Rostagno et al. (2011) for regular broilers considering a single phase of 28 days by adjusting the values presented in the phase from 22-33 days, either with or without exceeding the nutritional values (Table 1). Each box contained a pendulum water dispenser and a semi-automatic tubular feeder. The data on poultry weight, feed intake and mortality was recorded weekly for each box and used to evaluate broiler performance through total weight gain (WG), daily weight gain (DWG), viability index (VI), feed intake (FI) and feed conversion rate (FC) at 7, 14, 21 and 28 days.

All procedures in this study involving animals were in accordance with and duly approved by the Ethics Committee on Animal Use (CEUA/UFRA, protocol no. 027/2014).

\section{Economic viability}

Using data on broiler performance, and the cost of feed and chick acquisition, several indices were computed according to Espíndola (2011). The effective operational cost (EOC) is the cost effectively disbursed by the producer to produce a given quantity of a product. The operational expenses $(\mathrm{OE})$ and expenses contracted (EC) are included in the
EOC, and the costs of meals and chicks (I) are used for the calculation as follows: $\mathrm{EOC}=\mathrm{OE}+\mathrm{EC}+\mathrm{I}$ (all values in Brazilian real, $\mathrm{R} \$$ ). Gross earnings (GEa) represent the monetary value obtained from the sale of production and are calculated according to the production of chickens (in $\mathrm{kg}$ of live weight) and the selling price of the product $(\mathrm{R} \$ /$ $\mathrm{kg})$ as follows: $\mathrm{GE}=$ price per $\mathrm{kg}$ x quantity $(\mathrm{kg})$. The gross margin in relation to the effective operating cost (GMEOC) represents the percentage of resources remaining after the producer pays the effective operating cost (EOC) and considering the unit selling price of the product and its production as follows: GMEOC $(\%)=(\mathrm{GEa}-\mathrm{EOC}) / \mathrm{EOC}$ $\mathrm{x} 100$. The leveling point (LP) is a cost indicator for a given level of production cost where the minimum output must cover this cost given the unit selling price of the product and is claculated as: $\mathrm{LP}$ (unit) $=\mathrm{EOC} /$ live weight $(\mathrm{R} \$ / \mathrm{kg})$. The effective operational profit (EOP) is the profitability of an activity in the short term including the economic and operational conditions, thus: EOP $=\mathrm{GEa}-\mathrm{EOC}$. The profitability index (PI) is an indicator of the available rate of revenue of the activity after payment of operating costs, calculated as: PI (\%) = EOP / GEa x 100 .

\section{Data analysis}

The data on broiler performance and economic viability parameters were submitted to the Shapiro-Wilk normality test. Normally distributed variables were compared among treatments using analysis of variance (ANOVA), followed by the Tukey ad hoc pairwise comparison of means. Probability level was set at $5 \%$. All analyses were performed with SAS University Edition (2016).

\section{RESULTS}

The bromatological analysis (Table 2) indicated AsM is the best choice to compose the test rations for the chicken performance evaluation due to the higher level of crude protein, lower levels of NDF, ADF, and crude fiber. Since the açaí seed had relatively low protein content and energy density, it was necessary to increase the amount of soybean oil and soybean meal in the treatment feed formulations (Table 1), in order to maintain appropriate isoprotein and isoenergetic levels.

There was no significant difference among treatments for broiler weight gain and viability, but feed intake and feed convertion rate were significantly higher in T2 then in T3 (Table 3). T2 had the highest value for food intake and the highest feed conversion rate, while T3 had the lowest value for feed conversion rate among all treatments.

Regarding economic viability parameters, T3 had the highest cost per kilogram of feed, and the highest cost per kilogram of chicken produced, while T0 had the best economic parameters (Table 4). There was no significant 
difference among treatments for GEa, GMEOC, EOP and PI, however EOC and LP were significantly higher for T2 in comparison with T0, and EOC and LP did not differ statistically between $\mathrm{T} 3$ and $\mathrm{T} 0$ (Table 5).

Table 2. Bromatological composition of different components of the açaí fruit. $\mathrm{AcM}=$ açaí seed with mesocarp; $\mathrm{AsM}=$ açaí seed without mesocarp, expressed on dry basis. Values are mean \pm SD of five samples.

\begin{tabular}{lcc}
\hline Parameter & AcM & AsM \\
\hline Gross energy (cal/g) & $4417 \pm 0.02$ & $4304 \pm 0.01$ \\
\hline Moisture \% & $43.01 \pm 0.07$ & $31.14 \pm 0.05$ \\
\hline Dry matter \% & $56.99 \pm 0.27$ & $68.86 \pm 0.42$ \\
\hline Ether extract \% & $0.78 \pm 0.21$ & $1.42 \pm 0.19$ \\
\hline Crude protein \% & $2.86 \pm 0.03$ & $3.78 \pm 0.10$ \\
\hline Mineral matter \% & $1.27 \pm 0.04$ & $1.29 \pm 0.01$ \\
\hline Crude fiber \% & $80.52 \pm 0.56$ & $77.20 \pm 0.78$ \\
NDF \% & $87.02 \pm 0.32$ & $82.95 \pm 0.13$ \\
\hline ADF \% & $72.25 \pm 0.19$ & $46.53 \pm 0.50$ \\
\hline
\end{tabular}

Table 3. Means of performance parameters ( $N=8$ replicates per treatment) of slow-growing broilers in the initial phase ( 1 to 28 days) submitted to different treatments of inclusion of açaí seed bran in their diet. T0: control diet without açaí seed bran; T1: diet with $2 \%$ açaí seed bran; T2: diet with $6 \%$ açaí seed bran; T3: diet with $10 \%$ açaí seed bran. CV = coefficient of variance.

\begin{tabular}{lccccc}
\hline \multicolumn{7}{c}{ Treatments } \\
\hline Parameters & T0 & T1 & T2 & T3 & CV(\%) \\
\hline Initial weight (g) & 38.02 & 38.34 & 38.15 & 38.43 & 4.95 \\
\hline Weight gain (g) & 689.5 & 685.0 & 682.7 & 685.0 & 4.87 \\
\hline Feed intake (g) & $1.194^{\mathrm{ab}}$ & $1.206^{\mathrm{ab}}$ & $1.241^{\mathrm{a}}$ & $1.150^{\mathrm{b}}$ & $4.11^{*}$ \\
Feed convertion rate & $1.735^{\mathrm{ab}}$ & $1.766^{\mathrm{ab}}$ & $1.821^{\mathrm{a}}$ & $1.681^{\mathrm{b}}$ & $5.57^{*}$ \\
Viability (\%) & 99.03 & 99.03 & 95.19 & 98.07 & 3.96 \\
\hline
\end{tabular}

* indicates that coefficients varied significantly in ANOVA $(p<0.05)$. Letters group treatment means that do not differ significantly according to the Tukey test $(p<0.05)$.

Table 4. Production performance and production cost of slow-growth broilers in the initial growth phase (1 to 28 days) fed with diets containing different proportions of açaí seed bran. T0: control diet without açaí seed bran; T1: diet with 2\% açaí seed bran; T2: diet with 6\% açaí seed bran; T3: diet with 10\% açaí seed bran. Values for intake and average weight are the mean of eight replicates per treatments. Production cost values are from March 2016. All monetary values are in Brazilian real (R\$).

\begin{tabular}{lcccc}
\hline \multirow{2}{*}{ Production parameters } & \multicolumn{4}{c}{ Treatments } \\
\cline { 2 - 5 } & $\mathrm{T} 0$ & $\mathrm{~T} 1$ & $\mathrm{~T} 2$ & $\mathrm{~T} 3$ \\
\hline Initial ration $(\mathrm{R} \$ / \mathrm{kg})$ & 1.468 & 1.484 & 1.515 & 1.546 \\
Intake $(\mathrm{kg})$ & 1.195 & 1.207 & 1.242 & 1.151 \\
\hline Cost/phase (R\$/chicken) & 1.754 & 1.791 & 1.881 & 1.779 \\
Number of chickens/treatment & 103 & 103 & 99 & 102 \\
\hline Average weight $(\mathrm{kg})$ & 0.728 & 0.717 & 0.706 & 0.724 \\
\hline Cost per $\mathrm{kg}$ of chicken $(\mathrm{R} \$ / \mathrm{kg})$ & 2.409 & 2.497 & 2.664 & 2.457 \\
\hline
\end{tabular}

Table 5. Economic viability parameters estimated for slow-growth broilers at initial phase (1 to 28 days) submitted to different treatments of inclusion of açaí seed bran in their diet. T0: control diet without açaí seed bran; T1: diet with 2\% açaí seed bran; T2: diet with 6\% açaí seed bran; T3: diet with 10\% açaí seed bran. EOC = effective operational cost; $\mathrm{GEa}=$ gross earning; $\mathrm{GMEOC}=$ gross margin in relation to effective operational cost; $L P=$ leveling point; $E O P=$ effective operational profit; $\mathrm{PI}=$ profitability index in the production of an experimental unit ( 13 chickens per unit). All monetary values are in Brazilian real (R\$).

\begin{tabular}{lccccc}
\hline \multirow{2}{*}{ Parameters } & \multicolumn{5}{c}{ Treatments } \\
\cline { 2 - 5 } & T0 & T1 & T2 & T3 & \\
\hline EOC $(\mathrm{R} \$ / 13$ chickens) & $65.67^{\mathrm{b}}$ & $66.15^{\mathrm{ab}}$ & $67.32^{\mathrm{a}}$ & $65.99^{\mathrm{b}}$ & $1.45^{*}$ \\
$\mathrm{GEa}^{2}(\mathrm{R} \$)$ & 93.68 & 92.37 & 84.46 & 92.27 & 7.03 \\
$\mathrm{GMEOC}^{3}(\%)$ & 42.68 & 39.63 & 30.06 & 39.88 & 26.79 \\
$\mathrm{LP}^{4}(\mathrm{~kg})$ & $6.57^{\mathrm{b}}$ & $6.61^{\mathrm{ab}}$ & $6.73^{\mathrm{a}}$ & $6.60^{\mathrm{b}}$ & $1.45^{*}$ \\
$\mathrm{EOP}^{5}(\mathrm{R} \$)$ & 28.02 & 26.23 & 20.14 & 26.27 & 26.70 \\
$\mathrm{Pl}^{6}(\%)$ & 29.76 & 27.87 & 22.32 & 28.33 & 23.19 \\
\hline
\end{tabular}

'Sum of costs with feed + fixed cost + chick acquisition cost $(\mathrm{R} \$ 2.50 /$ individual) $\times 13$ chickens.

${ }^{2}$ Average weight $x$ number of poultry sold $x \mathrm{R} \$ 10.00$ per kg of live chicken.

${ }^{3}$ (GEa-EOC)/EOC $\times 100$.

${ }^{4} \mathrm{EOC} /$ selling price.

${ }^{5} \mathrm{EOP}=\mathrm{GEa}-\mathrm{EOC}$

${ }^{6} \mathrm{PI}=\mathrm{EOP} / \mathrm{GEa}$

* indicates that coefficients varied significantly in ANOVA $(p<0.05)$. Letters group treatment means that do not differ significantly according to the Tukey test $(\mathrm{p}<0.05)$

\section{DISCUSSION}

We were not able to find reference values in the literature for GE of any of the açaí components analyzed in here, which probably owes to that the the açaí pulp, which is the economically relevant fruit component, is usually the focus of nutritional research (Pessoa et al. 2010; Sangronis and Sanabria 2011; Yuyama et al. 2011). Our results differed from those of the pioneering work of Altman (1956), who found values of $13.60 \%$ moisture, $3.01 \%$ ether extract, and $4.34 \%$ crude protein for açaí seeds, although it is not clear which fraction of the seed was used, for the author referred only to "crushed açaí seed". Values for açaí seeds without mesocarp by Filho et al. (1987) were of $19.93 \%$ dry matter (well below our result), $2.45 \%$ crude protein, $0.98 \%$ ether extract, $78.25 \%$ $\mathrm{NDF}$ and $59.87 \% \mathrm{ADF}$ (all similar to our values). Townsend et al. (2001) also report similar values for açaí seeds without mesocarp, with $62 \%$ dry matter, $4 \%$ crude protein, $1.82 \%$ ether extract, $2.34 \%$ mineral matter, $93.9 \%$ NDF and $64.9 \%$ ADF. Bromatological parameters of the seeds may vary due to the influence of numerous factors, such as genetic diversity of the berries, harvest period, soil type and fertilization, location and climatic condition of planting, and differences in pulp extraction methods such as the quantity of water used and the length of time and temperature used during maceration (Cunha et al. 2012).

Both fractions of açaí residue evaluated in here showed medium levels of gross energy, low levels of crude protein, and high levels of fiber, when compared to the levels recommended by Rostagno et al. (2011) for broiler chicken. Thus, except for the percentage of fiber, which is a limiting factor for non- 
ruminants, the açaí seed can be considered an alternative ingredient with potential for use in slow-growing broiler diet.

The higher FC and lower FI in the 10\% ASB treatment was due to the higher proportion of soybean oil and meal in the formulation (see Table 1), which provided energy, and initially stimulated but then reduced the FI. The addition of lipids in the diet promotes an increase in caloric density, the extra-caloric effect, which consists of the increase in nutrient availability of the feed ingredients, and the extra-metabolic effect of the fat that results in improvement of the energy efficiency through the increase in feed net energy (Sakomura et al. 2004; Santos et al. 2014).

We found no published studies that tested alternative ingredients for feed of slow-growth broilers in the initial phase up to 28 days, in which the birds remain confined without access to the picket. The vast majority of studies evaluate birds in the later growth phase, when breeding takes place semiextensively with free access to the picket for a large portion of the day until slaughter (Santos et al. 2014; Veloso et al. 2014; Tavares et al. 2015). From a productivity point of view, ASB inclusion did not significantly affect weight gain and viability of the broilers in relation to the control, and the feed with $10 \%$ ASB inclusion resulted in significantly lower feed intake and lower feed conversion rate in relation to feed with $6 \%$ ASB. We may thus conclude that up to $10 \%$ ASB can be included in the diet for slow growth broiler chickens up to 28 days of age without compromising performance.

From the environmental point of view, the use of ASB in broiler feed, specially in higher proportions, as in the $10 \%$ ASB treatment, would contribute to the efficiency and sustainability in the açaí production chain in the northern region of Brazil, while also reducing the environmental impact generated by the accumulation of açaí waste deposits in nature.

Diets with highest levels of ASB had higher cost compared to the standard diet (3.20 and 5.31\%, respectively, for 6\% and $10 \%$ ASB inclusion). Since the proportion of soybean oil and meal had to be increased in the treatment feeds for nutricional reasons, the price of soybean oil $(\mathrm{R} \$ 3.20 / \mathrm{kg})$ was an important factor in the cost of feed when increasing ASB inclusion. However, the higher feed cost reflected the cost per kilo of chicken produced with the ASB diet of $10 \%$, even with lower broiler feed intake in this treatment. The cost per kilogram in the diet with $10 \%$ ASB was $1.99 \%$ more than the value for the control treatment. An additional advantage is that the açaí seed bran can be prepared in loco by producers at low cost, since only manual work with the use of simple equipment is necessary for processing the in natura seed residues.

The increase in EOC was associated mainly to the increase in feed cost. However, even with a higher proportion of soybean oil and meal, the $10 \%$ ASB feed had EOC and LP values statistically equal to those of the control treatment. In periods of off-season, where supply is scarce and prices are higher, ASB can be considered as an alternative to substitute corn for up to $10 \%$ in slow-growing chicken broiler rations, with the choice being at the producer's discretion, since economically there is no difference between it and the control ration. Future studies should evaluate other diet compositions using $\mathrm{ASB}$, including alternatives that are more financially feasible for small poultry producers.

\section{CONCLUSIONS}

Açaí seed bran can be included at proportions of up to $10 \%$ in diets for slow-growing broilers in the initial phase (from 1 to 28 days) without impairing performance. The $10 \%$ inclusion level was shown to be economically equal to the control treatment. The use of diets containing $10 \%$ of açaí seed bran for slow growth broiler chickens is thus a viable alternative for production and the reduction of negative impacts generated by residues in the environment.

\section{ACKNOWLEDGMENTS}

This research is part of the doctoral thesis of the first author and was supported by the Fundação Amazônica Paraense de Amparo a Estudos e Pesquisas - Fapespa.

\section{REFERENCES}

Altman, R.F.A. 1956. Estudo químico de plantas amazônicas. Boletim Técnico do Instituto Agronômico do Norte, Pará, 10p.

Arruda, J.C.B.; Martins, T.D.D.; Silva, J.H.V.; Silva, L.P.G.; Oliveira, E.R.A. 2008. Desempenho de leitóes submetidos a diferentes níveis de substituição da proteína do farelo de soja pela proteína do ovo desidratado. Acta Scientiarum Animal Sciences, 30: 401-405.

Braga, R.M.; Roque, M.S. 2008. Comercialização de Galinha Viva do Tipo "Caipira" em Boa Vista, Roraima. Centro de Pesquisa Agroflorestal de Roraima, Boa Vista, Roraima, 24p.

Camelo, L.C.L.; Lana, G.R.Q.; Santos, M.J.B.; Camelo, Y.A.R.P.; Marinho, A.L.; Rabello, C.B.V. 2015. Inclusão de farelo de goiaba na dieta de codornas européias. Ciencia Animal Brasileira, 16: 343-349.

Cassuce, D.C.; Tinôco, I.F.F.; Baêta, F.C.; Zolnier, S.; Cecon, P.R.; Vieira, M.F.A. 2013. Atualização das temperaturas de conforto térmico para frangos de corte de até 21 dias de idade. Engenharia Agricola, 33: 28-36.

Castilhos, L.F.F. 2012. Aproveitamento da fibra de coco. Instituto de Tecnologia do Paraná, Paraná, 29p.

Cunha, O.F.R.; Neiva, J.N.M.; Maciel, R.P.; Miotto, F.R.C.; Neiva, A.C.G.R.; Restle, J. 2012. Avaliaçáo bioeconômica do uso da torta de dendê na alimentação de vacas leiteiras. Ciencia Animal Brasileira, 13: 315-322.

Delgado, E.; Orozco, Y.; Uribe, P. 2013. Comportamiento productivo de pollos alimentados a base de harina de plátano considerando la relación beneficio costo. Zootecnia Tropical, 31: 279-290. 
Detmann, E.; Souza, M.A.; Valadares Filho, S.C. 2012. Métodos para Análise de Alimentos. INCT - Ciência Animal, Ed Visconde do Rio Branco, Suprema, 242p.

Espíndola, G.B. 2011. Revisão dos parâmetros não zootécnicos aplicados em nutrição de monogástricos. Expressão Gráfica e Editora, Fortaleza, 168p.

Filho, J.A.R.; Batista, H.A.M.; Camarão, A.P.; Silva, E.D. 1987. Composição química e digestibilidade "in vitro" da matéria seca de residuos agroindustriais no estado do Pará. EMBRAPA-CPATU, Pará, 6p.

Gomes, D.I.; Veras, R.M.L.; Alves, K.S.; Detmann, E.; Oliveira, L.R.S.; Mezzomo, R.; Santos R.B.; Barcelos, S.S. 2012. Performance and digestibility of growing sheep fed with açai seed meal-based diets. Tropical Animal Health And Production, 44: 1751-1757.

Guéguen, L. and Pascal, G. 2010. Le point sur la valeur nutritionnelle et sanitaire des aliments issus de l'agriculture biologique. Cahiers de Nutrition et de Dietetique, 45: 130-143.

IBGE. 2015. Instituto Brasileiro de Geografia e Estatística. SIDRA. ( http://www.sidra.ibge.gov.br/). Accessed on 13 July 2017.

Menezes, E.M.S.; Torres, A.T. and Srur, A.U.S. 2008. Valor nutricional da polpa de açaí (Euterpe oleracea Mart) liofilizad. Acta Amazonica, 38: 311-316.

Morais, J.; Ferreira, P.B.; Jacome, I.M.T.D.; Mello, R.; Breda, F.C.; Rorato, P.R.N. 2015. Curva de crescimento de diferentes linhagens de frango de corte caipira . Ciência Rural, 45: 1872-1878.

Moreira, A.S.; Santos, M.S.V.; Vieira, S.S.; Tavares, F.B.; Manno, M.C. 2012. Performance of broiler chickens fed diets containing different levels of metabolizable energy. Arquivo Brasileiro de Medicina Veterinaria e Zootecnia, 64: 1009-1016.

Nahashon, S.N.; Aggrey, S.E.; Adefope, N.A.; Amenyenu, A.; Wright, D. 2010. Gompertz-Laird model prediction of optimum utilization of crude protein and metabolizable energy by French guinea fowl broilers. Poultry Science, 89: 52-57.

Oliveira, M.S.P.; Neto, J.T.F. and Pena, R.S. 2007. Açaí : técnicas de cultivo e processamento. Editora do Instituto de Desenvolvimento da Fruticultura e Agroindústria - FRUTAL, Belém, Pará, 105p.

Pessoa, J.D.C.; Arduim, M.; Martins, M.A.; Carvalho, J.E.U. 2010. Characterization of Açaí (E. oleracea) fruits and its processing residues. Brasilian Archives of Biology and Technology, 53:1451-1460.

Rostagno, H.S.; Albino , L.F.T.; Donzele, J.L.; Gomes, P.C.; Oliveira, R.F.; Lopes, D.C.; Ferreira, A.S.; Barreto, S.L.T.; Euclides, R.F. 2011. Tabelas Brasileiras para Aves e Suinos. Ed. Universidade Federal de Viçosa, Viçosa, Minas Gerais, 252p.

Sangronis, E. and Sanabria, N. 2011. Impact of solar dehydration on composition and antioxidant properties of açaí (Euterpe oleracea Mart.). Archivos Latinoamericanos de Nutricion, 61: 74-80.
Santana, A.C.; Santana, A.L.; Santana, A.L.; Santos, M.A.S.; Pliveira, C.M. 2014. Análise discriminante múltipla do mercado varejista de açaí em belém do pará. Revista Brasileira de Fruticultura, 36: 532-54.

Santos, F.R.; Stringhini, J.H.; Minafra, C.S.; Almeira, R.R.; Oliveira, P.R., Duarte, E.F.; Silva, R.B.; Café, M. B. 2014. Formulação de ração para frangos de corte de crescimento lento utilizando valores de energia metabolizável dos ingredientes determinada com linhagens de crescimento lento e rápido. Arquivo Brasileiro de Medicina Veterinária e Zootecnia, 66: 1839-1846.

SAS Institute Inc. 2016. SAS ${ }^{\oplus}$ University Edition: Installation Guide for Windows. SAS Institute Inc., Cary, NC.

Sakomura, N.K.; Longo, F.A.; Rabelo, C.B.; Watanabe, K.; Pelicia, K.; Freitas, E. R. 2004. Efeito dos níveis de energia metabolizável da dieta no desempenho e metabolismo energético de frangos de corte. Revista Brasileira de Zootecnia, 33: 1758-1767.

Sousa, J.P.L.; Rodrigues, K.F.; Albino, L.F.; Santos Neta, E. R.; Vaz, R.G.M.V.; Parente, I.B.; Silva, G.F.; Amorim, A.F. 2012. Bagaço de mandioca em dietas de frangos de corte. Revista Brasileira de Saúde Produção Animal, 13: 1044-1053.

Tavares, F.B.; Santos, M.S.V.; Araújo, C.V.; Costa, H.S.; Loureiro, J.P.B.; Lima, E.M.; Lima, K.R.S. Performance, growth and carcass characteristics of alternatives lineages of broiler chickens created with access to paddock. 2015. Revista Brasileira de Saúde e Produção Animal, 16: 420-429.

Teixeira, L.B.; Germano, V.L.C.; Oliveira, R.F.; Junior, J.F. 2002. Processo de Compostagem a Partir de Lixo Orgânico Urbano e Caroço de Açaí. Ed. EMBRAPA Amazônia Oriental, CT/29, Pará, 8p.

Townsend, C.R.; Costa, N.L.; Pereira, R.G.A.; Senger, C.D.C. 2001. Características químico-bromatológica do caroço de açaí. Ed. EMBRAPA-CPAF, CT/193 Rondônia, 6p.

Veloso, R.C.; Pires, A.V.; Torres Filho, R.A.; Pinheiro, S.R.F.; Winkelstroter, L.K.; Alcântara, D.C.; Cruz, C.C.D.C.S. Parâmetros de desempenho e carcaça de genótipos de frangos tipo caipira. 2014. Arquivo Brasileiro de Medicina Veterinária e Zootecnia, 66: 1251-1259.

Yuyama, L.K.O.; Aguiar, J.P.L.; Filho, D.F.S.; Yuyama, K.; Varejão, M.J.; Fávaro, D.I.T.; Vasconceloes, M.B.A.; Pimentel, S.A.; Caruso, M.S.F. 2011. Caracterização físico-química do suco de açaí de Euterpe precatoria Mart . oriundo de diferentes ecossistemas amazônicos. Acta Amazonica, 41: 545-552.

RECEIVED: $13 / 11 / 2017$

ACCEPTED: $12 / 07 / 2018$

ASSOCIATE EDITOR: Rodrigo do Valle 